\title{
Investigation of Nasal Staphylococcus aureus carriage in hospital employees and rapid detection of PVL and mecA genes by RT-PCR
}

\author{
Dilek Dülger ${ }^{1}$ (), Seda Ekici² (), Özgür Albuz ${ }^{3}$ (), Ahu Pakdemirli ${ }^{4}$ (우 \\ ${ }^{7}$ Karabük University Faculty of Medicine, Department of Microbiology, Karabük/Turkey \\ ${ }^{2}$ Veterinary Control Central Research Institute, Ankara/Turkey \\ ${ }^{3}$ Keçiören Training and Research Hospital, Deparment of General Surgery, Ankara/Turkey \\ ${ }^{4}$ University of Health Sciences, Gulhane School of Medicine, Department of Physiology, Ankara/Turkey
}

Geliş Tarihi / Received: 05.05.2020, Kabul Tarihi / Accepted: 20.05.2020

\begin{abstract}
Staphylococcus aureus (S.aureus) can cause serious fatal infections due to several enzymes and toxins that it secretes when it encounters favorable conditions. Thus, S.aureus is one of the most important pathogens currently causing hospital and community infections. Methicillin-resistant S.aureus (MRSA) strains are resistant to many antibiotics and have the ability to rapidly develop resistance to currently used antibiotics during treatment. MRSA origins cause serious infections with high mortality and also increase the rate of hospital infections that require difficult and longer hospitalization and the use of greater quantities of antibiotics in risk-prone units in hospitals. Another factor that is as important as MRSA in S.aureus pathogenicity is the Panton-Valentine leucocidin (PVL) toxin secreted by S.aureus strains, most commonly isolated from deadly necrotizing pneumonias and community-acquired soft skin tissue infections. PVL is especially observed in community-acquired S.aureus strains. However, studies showed that PVL-positive origins began to spread rapidly to hospital environments. In this study, methicillin-sensitive S.aureus, methicillin-resistant coagulase-negative Staphylococcus (MR-CNS), and Panton-Valentine leukocidine genes were identified by real-time polymerase chain reaction (RT-PCR) by investigating the rate of nasal S.aureus carriers (NSAC) in nasal swab samples collected from hospital staff belonging to the highest risk group for staphylococcal infections, at which screening is aimed. Classical NSAC scans were performed on nasal swap samples collected from 98 healthcare professionals in Hospital. Nasal S.aureus (4 MSSA,13 MRSA) was detected in 17 samples(17.35\%). During detection, 48 MR-CNS were detected. In addition, 61 mecA (+), 17 nuc (+), 1 pvl (+) genes were detected in RT-PCR samples directly from the nasal swabs collected in accordance with the culture method.
\end{abstract}

Key words:, mecA, MRSA, nuc, pvl, S aureus.

\section{Hastane çalışanlarında Nazal Staphylococcus aureus taşıyıcılığı ve $P V L$ ile mecA genlerinin RT-PCR ile hızlı tespiti}

\begin{abstract}
Özet: Staphylococcus aureus (S. aureus) kommensal bir bakteri olarak hem insanla beraber yaşamakta, hem de fırsatçı olarak uygun koşulları bulduğunda salgıladığı bazı enzim ve toksinler nedeniyle çok ciddi ölümcül enfeksiyonlara neden olabilmektedir. Bu nedenle günümüzde $S$. aureus hastane ve toplum kaynaklı enfeksiyonlara neden olan en önemli patojenlerden biridir. Metisilin dirençli S. aureus (MRSA) kökenleri birçok antibiyotiğe karşı dirençlidirler ve tedavi süresince kullanılan günümüz antibiyotiklerine karşı çok hızlı bir şeklide direnç geliştirme kabiliyetine sahiptirler. Bundan dolayıdır ki MRSA enfeksiyonları normal S. aureus enfeksiyonlarına oranla daha şiddetli ve inatçı enfeksiyonlara neden olmaktadırlar. S. aureus patojenitesinde MRSA kadar önemli olan diğer bir etken, özellikle ölümcül nekrotizan pnömonilerden ve toplum kökenli deri, yumuşak doku enfeksiyonlarından izole edilen S.aureus suşları tarafından salgılanan Panton-Valentine lökosidin (PVL) toksinidir. PVL özellikle toplum kökenli S.aureus suşlarında gözlenmektedir. Ancak yapılan çalışmalar PVL pozitif kökenlilerin hastane ortamlarına hızla yayılmaya başladığını göstermiştir. Bu çalışmada stafilokok enfeksiyonları için en yüksek risk grubunda yer alan hastane personelinden alınan nazal swap örneklerinde nazal S.aureus taşıyıcılığı (NSAT) oranının araştırılması ile rt-PCR ile Metisiline Duyarlı S. aureus, Metisiline Dirençli Koagülaz Negatif Stafilokok ve Panton-Valentine lökosidin virülans genlerin taramasının yapılması amaçlanmıştır. Devlet hastanesinde çalışan personelden alınan nazal swap örneklerinden klasik NSAT taraması yapılmış 98 sağlık personelinin 17'sinde (\%17,35) nazal S.aureus taşıyıcılığı (4'ü MSSA, 13'ü MRSA ) saptanırken, 48'inde MR-KNS tespit edilmiştir. Ayrıca alınan nazal swablardan direk olarak yapılan RT-PCR örneklerinde kültür metodu ile birebir uyumlu olarak $61 \operatorname{mecA}(+), 17$ nuc(+), 1 pvl(+) genleri tespit edilmiştir.
\end{abstract}

Anahtar kelimeler: $m e c A, M R S A, n u c, p v l, S$ aureus.

Yazışma adresi / Correspondence: Seda Ekici, Ahmet Şefik Kolaylı Cad. No: 23-1 06200, Keçiören-Ankara E-posta: seda.ergen@hotmail.com

ORCID IDs of the authors: '0000-0003-3640-5686 • 20000-0002-7982-5261 • ${ }^{3} 0000-0002-8534-1781$

. ${ }^{40000-0001-9224-3007 ~}$ 


\section{Introduction}

Staphylococcus aureus (S. aureus) is a commensal pathogen that lives in close proximity to humans and causes opportunistic serious infections when it finds suitable conditions (Tong et al. 2015). S aureus colonization takes place in the normal flora in many body regions, especially the skin and mucous membranes in the mammalian (Haag et al. 2019). S. aureus is mostly observed in the nasal mucosa and reports suggest that it is transported in the nasal mucosa in $20 \%-30 \%$ of the population (Lee et al. 2018). When mucosal and cutaneous barriers break down in the normal nasal mucosa, S. aureus can enter the bloodstream and cause serious infections in the heart, skin, soft tissues, bones and joints (Peacock and Paterson 2015). The pathogenicity of $S$. aureus varies according to the fact that Panton-Valentine leukocidin (PVL) carry a toxin and originate from methicillin-resistant S. aureus (MRSA) (Gordon and Lowy 2008).

MRSA resistance, which is increasingly relevant worldwide, results from a modified protein called penicillin-binding protein 2a/2 '(PBP2a/PBP2') encoded by the mecA gene (Sardan 2000, Zhu et al. 2006). MRSA strains with the mecA gene are resistant to all beta-lactams and beta-lactam-derived antibiotics (Ozel et al. 2011; Keyvan and Ozdemir, 2016).

The epidemiology and characteristics of MRSA differ in different geographic regions. With the increase in resistance problems in infections caused by MRSA, MRSA has become a serious health problem causing nosocomial epidemics worldwide (Bastidas et al. 2019). The origins of MRSA are categorized as hospital-associated (HA-MRSA) and community- associated (CA-MRSA). Compared to HA-MRSA strains, CA-MRSAs are generally sensitive to macrolides and fluoroquinolone antibiotics and are capable of producing $P V L$ toxins (Deurenberg et al. 2004). PVL is a two-component cytotoxin that can render defense cells inactive by creating pores in immune system cells, including basophils, leukocytes, monocytes, and macrophages, in the human body (Meyer et al. 2009). The high virulence potential of CA-MRSA strains containing the PVL gene is due to the suppression of leukocytes during infection (Vandenesch et al. 2009). The PVL gene plays a critical role in the escape of $S$. aureus from the immune system and the clinical course is quite severe in the infections it causes (McDonald et al. 2005). Death is more common in CA-MRSA infections with PVL toxin, and the PVL gene is particularly observed in CA-MRSA strains. However, studies have shown that PVL-positive strains begin to spread rapidly in hospital settings (Duman et al. 2013). Besides, it is reported that $20 \%-30 \%$ of hospitalized patients are colonized with the strain that is common in that hospital within the first 5-10 days (Uluğ 2012). Therefore, the rapid detection of microorganisms colonized in hospitals by molecular methods is a very important issue for both the treatment process and the implementation process of infection-control policies in the context of public health (Navarro et al. 2008). Further, although some CA-MRSA isolates contain the mecA gene, the methicillin minimum inhibitory concentration (MIC) values can be very low. In antibiotic susceptibility tests, these can result in mistaken indentification as methicillin-sensitive S. aureus (MSSA). For this reason, it is recommended that the presence of the mecA gene be determined by $P C R$, considering that resistance cannot be detected in serious infections that do not respond to treatment (Gülay 2008). In addition, this method of determining the resistance of methicillin in MRSA strains, which are prominent with multiple resistances, is reliable, easy to apply, and gives quick results in routine laboratories. Therefore, in terms of infection-control policies, the method is very important in both treatment and application processes (Teng et al. 2009).

In this study, the mecA gene, which is the gold standard for determining the resistance of methicillin with both the classical culture and real-time polymerase chain reaction (RT-PCR), and the PVL virulence gene in MSSA and MRSA were scanned in nasal swab samples collected from health personnel working at 29 Mayıs State Hospital in Ankara.

\section{Materials and Methods}

Ethics committee approval was obtained from the Health Sciences University Dışkapı Yıldırım Beyazıt Training and Research Hospital Clinical Research Ethics Committee. With the approval of the ethics committee dated September 12, 2019 and numbered 77/18, 98 swab samples were collected from sterile swabs soaked in sterile saline from both nostrils of health personnel working in the 29 May State Hospital.

\section{Determination of Bacteria Isolation and Methicillin Resistance}

Samples were inoculated on 5\% sheep-blood agar by using single streak colony reduction method. Those samples were incubated at $35^{\circ} \mathrm{C}$ for another 
$24 \mathrm{~h}$, in which more than 10 colonies considered to be significant grew on the plate, and samples those grown fewer colonies were not considered.

After the colony morphology was examined, Gram staining was performed, and those strains with gram-positive cocci morphology were included in the study, and catalase, coagulase tests were performed. Those strains with positive catalase and coagulase tests were classified as $S$. aureus. The cefoxitin disk was used to determine methicillin resistance. A suspension of $0.5 \mathrm{McF}$ arland turbidity was prepared from the isolates and applied to Mueller Hinton agar (Merck, Germany). Thirty micrograms of cefoxitin disks (Oxoid) were placed on the medium and incubated at $35^{\circ} \mathrm{C}$ for $24 \mathrm{~h}$. Isolates with zone sizes $\leq 21 \mathrm{~mm}$ were considered to be methicillin resistant (CLSI, 2015). The cefoxitin diskdiffusion $(30 \mu \mathrm{g})$ method, which has higher sensi- tivity and specificity than the oxacillin disk-diffusion test, was used to determine methicillin resistance in the CNS (Swenson et al. 2007). S. aureus ATCC 25923 and ATCC 43300 were used as control strains.

\section{In-house Real-Time Polymerase Chain Reaction}

In the triplex real-time PCR study, the primers to be used for the detection of $P V L$, mecA (for the detection of methicillin resistance), and nuc (for the identification of $S$. aureus) genes were synthesized by Macrogen Inc. considering the base pairs indicated by Galia et al. (Table 1).

Nasal swabs from ATCC 25923 (MSSA) and ATCC 43300 (MRSA) were used as a negative control with reference ATCC 25922 E. coli strain. DNA isolation with a Bacterial DNA isolation kit (AMBRD, Turkey) according to the kit protocol was performed by Soygen Biotechnology.

Table 1. Primers and probes used in the study (Galia et al. 2019).

\begin{tabular}{|c|c|c|c|c|c|}
\hline & GenBank ${ }^{\circledR}$ Access number & Primer/Probe & & Position & Base pair \\
\hline \multirow{3}{*}{ mecA } & \multirow{3}{*}{ KC243783.1 } & mecA fw & CAATGCCAAAATCTCAGGTAAAGTG & $1931-1957$ & \multirow{3}{*}{107} \\
\hline & & mecA rev & AACCATCGTTACGGATTGCTTC & 2018-2018 & \\
\hline & & mecA Probe & CY5-ATGAGCTATATGAGAACGG-BHQ2 & 1958-1979 & \\
\hline \multirow{3}{*}{ pvl } & \multirow{3}{*}{ X72700.1 } & $p v l \mathrm{fw}$ & AAATGCTGGACAAAACTTCTTGG & $606-624$ & \multirow{3}{*}{108} \\
\hline & & $p v l$ rev & TTTGCAGCGTTTTGTTTTCG & $693-712$ & \\
\hline & & pvl Probe & HEX-AAATGCCAGTGTTATCC-BHQ1 & $636-653$ & \\
\hline \multirow{3}{*}{ nuc } & \multirow{3}{*}{ DQ50738 } & nuc fw & GGCATATGTATGGCAATTGTTTC & $25-48$ & \multirow{3}{*}{73} \\
\hline & & nuc rev & CGTATTGCCCTTTCGAAACATT & $76-97$ & \\
\hline & & nuc Probe & FAM-ATTACTTATAGGGATGGCTATC- BHQ1 & $49-71$ & \\
\hline
\end{tabular}

An optimization study was performed with ATCC 25923 (MSSA) and ATCC 43300 reference strains to determine the optimal working concentration of synthesized primers and probes. According to the results of this study, $10 \mu \mathrm{l}$ DNA, $2.5 \mu \mathrm{l}$ primers (900 $\mathrm{nM})$ and probe $(250 \mathrm{nM})$, and $10 \mu \mathrm{l}$ master mix were arranged in $25 \mu \mathrm{l}$ reactions. The heat cycle was adjusted as $95^{\circ} \mathrm{C}$ predenaturation for $5 \mathrm{~min}, 40$ cycles of two steps at $95^{\circ} \mathrm{C}$ for $15 \mathrm{~s}$ for denaturation, and $60^{\circ} \mathrm{C}$ for $30 \mathrm{~s}$ for binding elongation.

\section{Results}

In the current study, the classical culture and triplex real-time PCR methods were applied to the nasal swab samples of 98 healthcare workers. The results obtained with the culture method and triplex realtime PCR method (Table 1) were $100 \%$ compatible.

In the triplex real-time PCR results from the 98 nasal swab samples included in the study, the nuc gene in 17 samples, the mec $A$ gene in 61 samples, and the pvl gene in only one sample were determined in a short time. Among the results obtained with the classical culture and triplex real-time PCR methods, 13 MRSA, 4 MSSA, $48 \mathrm{MR}-\mathrm{CN}$ and $25 \mathrm{MS}$ CNS isolates were detected, while eight of them could not be detected. These results given in Table 2. Today, although PVL strains begin to spread rapidly in hospital settings, in this study, only 1 of 98 healthcare personnel was found to have a positive PVL gene.

Table 2. Result of Triplex Real-time PCR test of 98 nasal swab samples

\begin{tabular}{ccccc}
\hline \multicolumn{3}{c}{ nuc (+) } & & nuc (-) \\
\hline & 17 & & 81 \\
mecA(+) MRSA & & mecA(-) MSSA & mecA(+)MR-KNS & mecA(-) MS-KNS or Stafilokok(-) \\
13 & & 4 & 48 & 33 \\
\hline
\end{tabular}




\section{Discussion}

S. aureus is one of the pathogenic microorganisms, which can be found in the mucous membranes of the skin, upper respiratory system, lower urogenital system and digestive system of animals and humans (Ozel et al. 2011; Keyvan and Özdemir, 2016). Also, $S$. aureus is one of the leading pathogens causing subclinical mastitis in dairy animals. Therefore, it causes contamination in milk and dairy products. They cause food poisoning with the different types of heat resistant enterotoxins produced. S. aureus is one of the most important factors of nosocomial infections. S. aureus quickly gains multiple antibiotic resistance, causing nosocomial and community related infections (Keyvan and Özdemir, 2016).

In terms of community health, rapid and accurate detection of hospital-borne MRSA isolates is crucial for the control of infection and the prevention of the nosocomial spread of bacteria. It has been determined that the spread of staphylococcal infections in the hospital environment occurs predominantly through the hands and clothes of the healthcare personnel. For this reason, healthcare personnel identified as nasal S.aureus carriers (NSAC) are an important source of transmission for MRSA (Uluğ 2012). In this study, the mecA, nuc, and PVL genes were scanned in nasal swab samples collected from health personnel working at the 29 Mayıs State Hospital using both the classical culture and triplex real-time PCR methods. While 13 MRSA, 4 MSSA, 48 methicillin-resistant coagulase-negative Staphylococcus (MR-CNS), and 25 MS-CNS isolates were detected in the 98 nasal swab samples included in the study, in eight of them Staphylococcus spp. could not be detected. Staphylococcus spp. was detected in 90 (91.83\%) of the 98 nasal swab samples included in the study, and the NSAC rate of healthcare professionals working at 29 Mayıs State Hospital was determined as $17.34 \%$. Furthermore, MR-CNS was detected in $48.97 \%$ of hospital staff. It is thought that the high rate of NSAC and MR-CNS in hospital personnel is due to the collection of nasal swabs during the winter period when the rate of upper respiratory tract infections is highest.

It is known that the determination of methicillin resistance is very important for the course and treatment of $S$. aureus infections. False-negative results can cause inadequate treatment during infection as well as the spread of MRSA origin in the community and transmission even to healthy individuals without any risk factors. Treatment options are restricted in infections caused by MRSA, and mortality and morbidity increase. Furthermore, false-positive results lead to unnecessary use of antibiotics in patients (Telli et al. 2006). Therefore, the rapid and reliable detection of MRSAs, which can rapidly develop resistance to currently used antibiotics, is very important for public health. Furthermore, the method chosen for determining resistance must be able to be used in routine laboratories and to be easily applied.

Although there are multiple methods to identify and confirm methicillin resistance in $S$. aureus strains, the time required to obtain results with conventional methods varies between $2-4$ days (Özen et al. 2011). Currently, thanks to technological progress, MRSA verification can be performed in $3 \mathrm{~h}$ using molecular methods such as PCR (Kuzucu et al. 2002; Cesur et al. 2010; Okolie et al. 2015).

In a study by Okolie et al. (2015), nuc and spa genes were detected using pentaplex PCR for the detection of $S$. aureus in clinical samples. In this study, PCR analysis was performed after pre-enrichment of the samples. Galia et al. (2019), on the other hand, determined the rate of MSSA, MRSA, and MR-KNS in conventional rectal and pharyngeal swabs using triplex real-time PCR. In the study, the authors differentiated MRSA, MSSA, and MR-KNS through the direct detection of nuc and mecA genes in a short time $(3 \mathrm{~h})$ using triplex real-time PCR without any enrichment of the swab samples. Furthermore, Galia et al. (2019) detected the PVL gene in their study. In the current study, both classical and molecular methods were compared and one-to-one compatibility was found between the methods. J.R.Perez et al. found that all MRSA isalates carry the PVL gene in their study. When we compared our results with the literature, we found that PVL gene positivity in $S$. aureus carriers in our hospital was very low. In our study, only one of the 13 MRSA positive cases was positive (Pérez et al. 2011).

Even though PVL gene positivity, which has an important role in bacterial virulence in our study, is very low, it is an issue to be kept in mind in common and persistent MRSA (+) hospital infections considering its role in infectiousness. Triplex real-time PCR is very important in the implementation of treatment and infection-control strategies for rapid and reliable results that can be obtained in a short time (3-4 h) for MRSA confirmations, which are of great importance for public health.

\section{References}

1- Bastidas CA, Villacrés-Granda I, Navarrete D, Monsalve M, Coral-Almeida M, Cifuentes SG. (2019) Antibiotic susceptibility profile and prevalence of mecA and lukS-PV/lukF-PV 
genes in Staphylococcus aureus isolated from nasal and pharyngeal sources of medical students in Ecuador. Infect Drug Resist. 12, 2553-2560.

2- Cesur $S$, Yildiz E, Irmak H, Aygün $Z$, Karakoç E, Kinikli $S$ Demiröz AP. (2010) Evaluation of oxacillin resistance screening agar and chromogenic MRSA agar media for the detection of methicillin resistance in Staphylococcus aureus clinical isolates. Mikrobiyol Bul. 44(2), 279-284

3- CLSI. (2015) CLSI-Clinical and Laboratory Standards Institute. Performance Standards for Antimicrobial Sensitivity Testing. Standard M100-S25. Volume 33, Number 3. Wayne, PA

4- Deurenberg RH, Vink C, Driessen C, Bes M, London N, Etienne J, Stobberingh EE. (2004) Rapid detection of PantonValentine leukocidin from clinical isolates of Staphylococcus aureus strains by real-time PCR. FEMS Microbiol Lett. 240(2), 225-228.

5- Duman Y, Tekerekoğlu MS, Otlu B. (2013) Toplum ve hastane kökenli Staphylococcus aureus klinik izolatlarında PantonValentine lökosidin varlığının ve klonal ilişkinin araştııılması. Mikrobiyol Bul. 47(3), 389-400.

6- Galia L, Ligozzi M, Bertoncell A, Mazzariol A. (2019) Real-time PCR assay for detection of Staphylococcus aureus, PantonValentine Leucocidin and Methicillin Resistance directly from clinical samples. AIMS Microbiol. 5(2), 138-146.

7- Gordon RJ, Lowy FD. (2008) Pathogenesis of methicillin-resistant Staphylococcus aureus infection. Clin Infect Dis. 46(5), 350-359.

8- Gülay Z. (2008) Gram Pozitif Bakteri İnfeksiyonları: Direnç ve Epidemiyoloji. ANKEM Derg. 22, 276-286.

9- Haag AF, Fitzgerald JR, Penadés JR. (2019) Staphylococcus aureus in Animals. Gram-Positive Pathogens, 731-746.

10- Keyvan E, Özdemir H. (2016) Sığır karkaslarında Staphylococcus aureus'un varlığı, enterotoksijenik özellikleri ve antimikrobiyal dirençliliği. Ank Üni Vet Fak Derg, 63 (1), 17-23.

11- Kuzucu C, Dalgalar M, Durmaz R, Dikerel S. (2002) Comparison of methods used to detect methicillin resistance in staphylococci. Mikrobiyol Bul. 36(3-4), 253-257.

12- Lee AS, de Lencastre $H$, Garau J, Kluytmans J, MalhotraKumar S, Peschel A, Harbarth S. (2018) Methicillin-resistant Staphylococcus aureus. Nat Rev Dis Primers. 4, 1-23.

13- McDonald RR, Antonishyn NA, Hansen T, Snook LA, Nagle E., Mulvey MR, Levett PN, Horsman GB. (2005) Development of a triplex real-time PCR assay for detection of PantonValentine leukocidin toxin genes in clinical isolates of methicillin-resistant Staphylococcus aureus. J Clin Microbiol. 43, 6147-6149.

14- Meyer F, Girardot R, Piemont Y, Colin DA. (2009) Analysis of the specificity of Panton-Valentine leucocidin and gammahemolysin F component binding. Infect Immun. 77, 266-273.

15- Navarro MB, Huttner B, Harbarth S. (2008) Methicillinresistant Staphylococcus aureus control in the 21 st century: beyond the acute care hospital. Curr Opin Infect Dis. 21:372379.
16- Okolie CE, Wooldridge KG, Turner DP, Cockayne A, James R. (2015) Development of a new pentaplex real-time PCR assay for the identification of poly-microbial specimens containing Staphylococcus aureus and other staphylococci, with simultaneous detection so staphylococcal virulence and methicillin resistance markers. Mol Cell Probes. 29, 144-150.

17- Ozel G, Aslan V, Bahar Erdem G, Cagatay M, Sencan I, Mert A. (2011) Comparison of oxacillin, cefoxitin, ceftizoxime, and moxalactam disc diffusion methods for detection of methicillin susceptibility in staphylococci. Mikrobiyol Bul. 45(2), 258-265.

18- Özen NS, Dağlar D, Özhak Baysan B, Yıldırım Ç, Yazısız H, Ogunç D, Öngüt G, Çolak D, Gültekin M. (2011) Metisilin dirençli Staphylococcus aureus suşlarının saptanmasında MRSA ID kromojenik besiyerinin değerlendirilmesi. ANKEM Derg. 25(1):31-34.

19- Peacock SJ, Paterson GK. (2015) Mechanisms of methicillin resistance in Staphylococcus aureus. Annu Rev Biochem. 84(1), 577-601.

20- Pérez JR, Tapia CO, Herazo CH, Ramos NR. (2011) Nasal Carriage of Panton Valentine Leukocidin-Positive MethicillinResistant Staphylococcus aureus in Healthy Preschool Children. Rev Salud Publica (Bogota). 13(5), 824-32.

21- Sardan, YC. (2000) Metisilin dirençli Staphylococcus aureus infeksiyonlarının epidemiyolojisi ve kontrolü. Hast infek Derg. 4, 205-217.

22- Swenson JM, Lonsway D, McAllister S, Thompson A, Jevitt L, Zhu W, Patel JB. (2007) Detection of mecA-mediated resistance using reference and commercial testing methods in a collection of Staphylococcus aureus expressing borderline oxacillin MICs. Diagn Microbiol Infect Dis. 58, 3-39.

23- Telli M, Sümerkan B, Eşel D. (2006) Staphylococcus aureus'ta metisilin direncinin belirlenmesinde sefoksitin disc, oksasilin disc, oksasilin agar tarama ve PBP2a lateks testlerinin karşılaştırılması. Infeksiyon Derg. 20(2), 93-96.

24- Teng CS, Lo WT, Wang SR, Tseng MH, Chu ML, Wang CC. (2009) The role of antimicrobial therapy for treatment of uncomplicated skin and soft tissue infections from communityacquired methicillin-resistant Staphylococcus aureus in children. J Microbiol Immunol Infect. 42, 324-328.

25- Tong SYC, Davis JS, Eichenberger E, Holland TL, Fowler VG. (2015) Staphylococcus aureus infections: epidemiology, pathophysiology, clinical manifestations, and management. Clin Microbiol Rev. 28(3), 603-661.

26- Uluğ M. (2012) Ameliyathane ve Yoğun Bakım Personelinde Nazal Staphylococcus aureus Taşıyıcılığının Araştırılması. Med Bull of Haseki. 50(2), 48-52.

27- Vandenesch F, Lina G, Gillet Y, Etienne J, Cremieux AC. (2009) The end of the controversy: Panton Valentine is the culprit. Med Sci. 25, 984-986.

28- Zhu LX, Zhang ZW, Wang C, Yang HW, Zhang Q, Cheng J. (2006) Evaluation of the CLSI cefoxitin 30-microg diskdiffusion method for detecting methicillin resistance in staphylococci. Clin Microbiol Infect.12(10),1039-1042. 